\title{
Successful Re-establishment of a Native Savannah Flora and Fauna on the Site of a Former Pine Plantation at Constance Bay, Ottawa, Ontario
}

\author{
P. M. Catling And B. Kostiuk
}

Agriculture and Agri-Food Canada, Environmental Health, Biodiversity, Saunders Building, Central Experimental Farm, Ottawa, Ontario K1A 0C6 Canada; e-mail: catlingp@agr.gc.ca

Catling, P. M., and B. Kostiuk. 2010. Successful re-establishment of a native savannah flora and fauna on the site of a former pine plantation at Constance Bay, Ottawa, Ontario. Canadian Field-Naturalist 124(2): 169-178.

To determine the extent of successful restoration of native savanna vegetation at The Sandhills, an unusual and biodiversityrich habitat in the Ottawa Valley, we gathered information from quadrats along transects so as to compare a restored clearing with the surrounding plantation. We provide an indication of success with respect to amount of effort and provide an example of some considerations and procedures for estimating success. With a minimum effort of tree cutting and bulldozing, removal of pine duff and litter, that is estimated to have required five people over a period of less than two weeks, a hectare was successfully restored to pre-settlement savannah vegetation. Apart from a limited seeding effort following the removal of planted trees, the re-establishment of native vegetation proceeded naturally, and it was likely aided by dispersal of seed from adjacent remnant vegetation along paths and firebreaks in the vicinity. Biodiversity, based on number of species and various indices, was substantially greater in the restored clearing than in the adjacent Red Pine platation. The semi-open Jack Pine plantation accommodated species of both shaded and open habitats and diversity approached that of the clearing. However, some species such as blueberry were in poor condition in the plantation, generally not producing flowers or fruit. In addition the non-dominant vegetation was much less of the cover. In the restored area there were more regionally rare species and much greater development of flowering herbaceous species and shrubs. Orthopteran insects, a useful indicator group of plant feeding species, had much higher diversity and abundance in the restored area. Savannah and natural sand barren that have been largely destroyed by plantation forestry can be restored successfully and inexpensively, and there is thus no reason why such restorations should not include large areas and be implemented widely. Among the tools for evaluating success are historical descriptions and various measures of biodiversity and vegetation condition.

Key Words: savannah, restoration, pine plantation, tree planting, species at risk, threatened, Ottawa, Ontario.

The loss of natural habitat to conifer plantations has occurred around the world. Recognition of this problem over the last several decades has led to removal of plantations and restoration of original vegetation in many areas. Some restoration projects have been extensive such as the replacement of a 2000 ha Pinus radiata plantation with indigenous plant communities in Australia (Kasel and Meers 2004*) .

In North America, savannahs and sand barrens are among the natural habitats often destroyed by development of conifer plantations. These habitats are also among the most imperilled of North American ecosystems (Noss et al. 1995). The problem is particularly well known in the southeastern United States where, prior to European settlement, extensive areas of speciesrich Longleaf Pine (Pinus palustris) savannahs were maintained by naturally occurring, relatively frequent, low intensity fires (Taggart 1990*). By the 1950s the suppression of fire, logging, conversion of the landscape to agriculture and pine plantation forestry had reduced the ecosystem to scattered remnants amounting to less than $3 \%$ of the original area. Today the remnants of this formerly predominant ecosystem are the focus of major restoration efforts, many of which involve clearing of pine plantations (Gilliam and Pratt 2006; Brudvig et al. 2009). In the northern lower
Michigan portion of the Great Lakes region, the once extensive Jack Pine barrens, have been mostly converted to managed Jack Pine plantations. These plantations are now being managed to create openings (Houseman and Anderson 2002) to restore the former barrens habitat for the endangered Kirtland's Warbler (Dendroica kirtlandii).

In Ontario between 1950 and 1970, extensive areas of open land, particularly dry, sandy, areas (including native savannahs), were planted with pines. These trees do well (especially with a head start) under dry conditions. This action was a leftover from a period when conservation was often seen in the limited context of erosion control. It was before the International Biological Program (IBP) that focused attention on ecosystems, ecology and significant natural habitats. The idea of the plantations was to prevent wind erosion resulting from intensive and poor agricultural practices and to increase productivity and value of idle land, often referred to as "wasteland." In 1971, Doug Clarke, former Chief of Wildlife Branch of the Ontario Department of Lands and Forests (and one of the most forward thinking biologists of the time), wrote of the unfortunate loss of the wildlife habitats (of Field, Grasshopper and Henslow's sparrows, etc.) to pine plantations throughout southern Ontatio. He correctly observed 


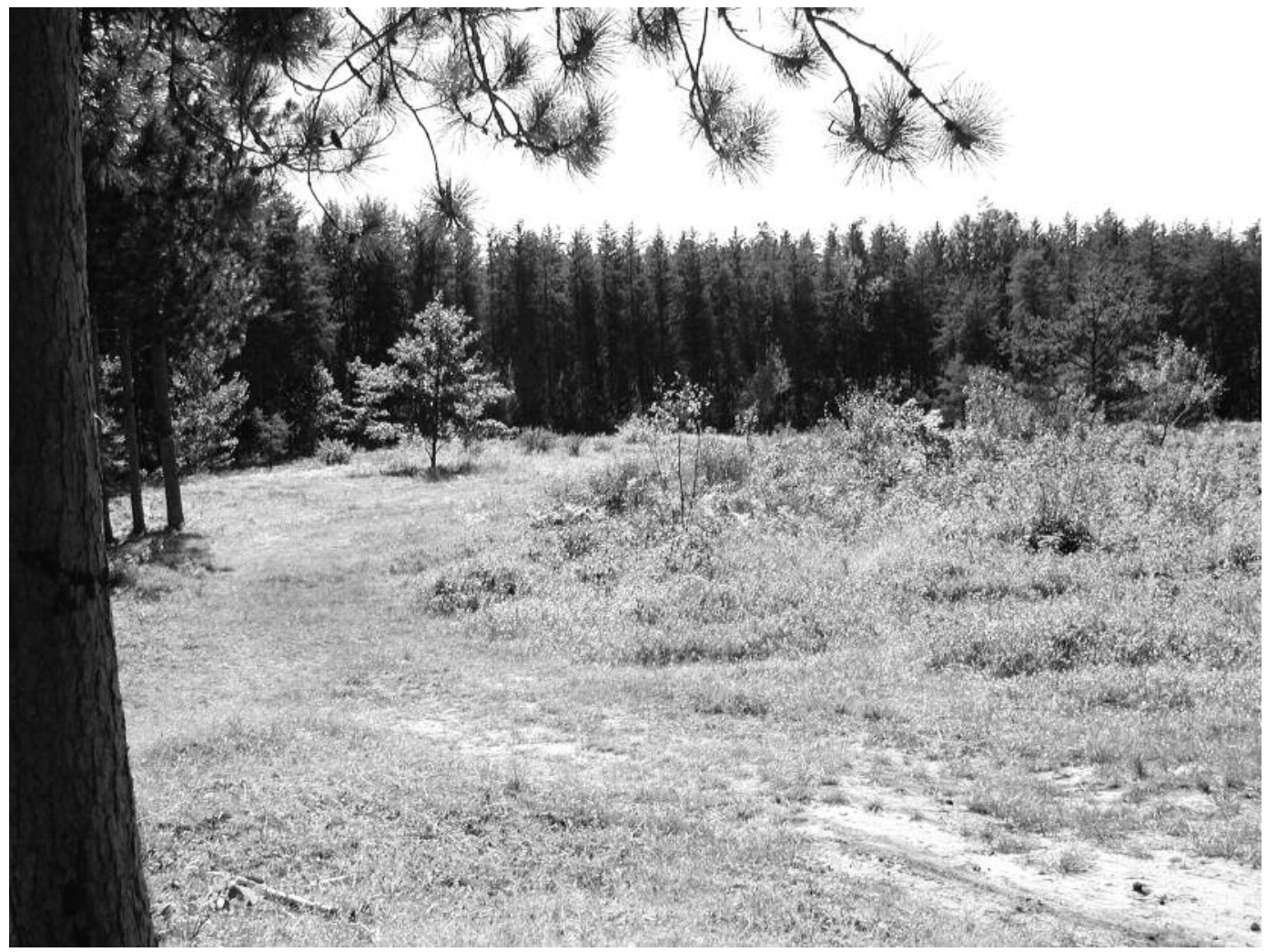

FIGURE 1. A clearing of the planted forest created in the late 1980s as part of an attempt to restore a portion of The Sandhills ecosystem. The line of transect 1 crosses the opening perpendicular to the line of vision in the centre of the photo. Looking southwest from the northeast corner. Photo by P. M. Catling, September. 2009.

that "more wildlife species like it open, that edges and openings are the places for wildlife, and the great wildlife spectacles of the earth are on treeless, or nearly treeless lands." It is not always necessary to plant pines to restore wasteland (e.g., Catling and King 2008) and planting non-native pines has led to substantial losses of native biodiversity (e.g., Catling and Carbyn 2005). In some cases the "wastelands" of Ontario that were planted with pines were special places with large numbers of native species including many rarities. As a result of plantation forestry, they were largely reduced to monocultures of a single species of tree; species diversity declined and some, or many, rare species were extirpated. The Constance Bay Sandhills on the Ottawa River provide one of hundreds of examples of this largely unconscious depletion of natural resources during the middle $20^{\text {th }}$ century (Catling et al. 2010). The Sandhills were, and to a degree still are, one of the biodiversity gems in the Ottawa valley, that was largely destroyed by conversion to a pine plantation.

Now that the importance of protecting biodiversity is more widely understood, complaints about the earlier misguided tree planting are frequent, but serious suggestions for restoration are few. Fewer still have been the attempts at restoration, although they are ongoing and the thinning and removal of plantations is a part of these restorations as for example in the Rice Lake Plains area of southern Ontario (Ontario Ministry of Natural Resources 2009*). Comprehensive evaluations of the success of restoration of savannah from pine plantation in Ontario are non-existent, yet landscape managers are in the position of making decisions on the basis of costs and benefits and restoration of imperiled savannah ecosystems in Ontario is a high priority (Bakowsky and Riley 1994; Rodger 1998).

The Constance Bay Sandhills, also known as Torbolton Forest (when the unique landscape could no longer be seen for the trees) is one of the few places in Ontario where restoration has been attempted. Here we evaluate the results of that effort to provide a basis for future restoration of savannahs and sand barrens. Specifically we provide an indication of success with respect to the amount of effort and provide an example of some considerations and procedures for estimating success. 


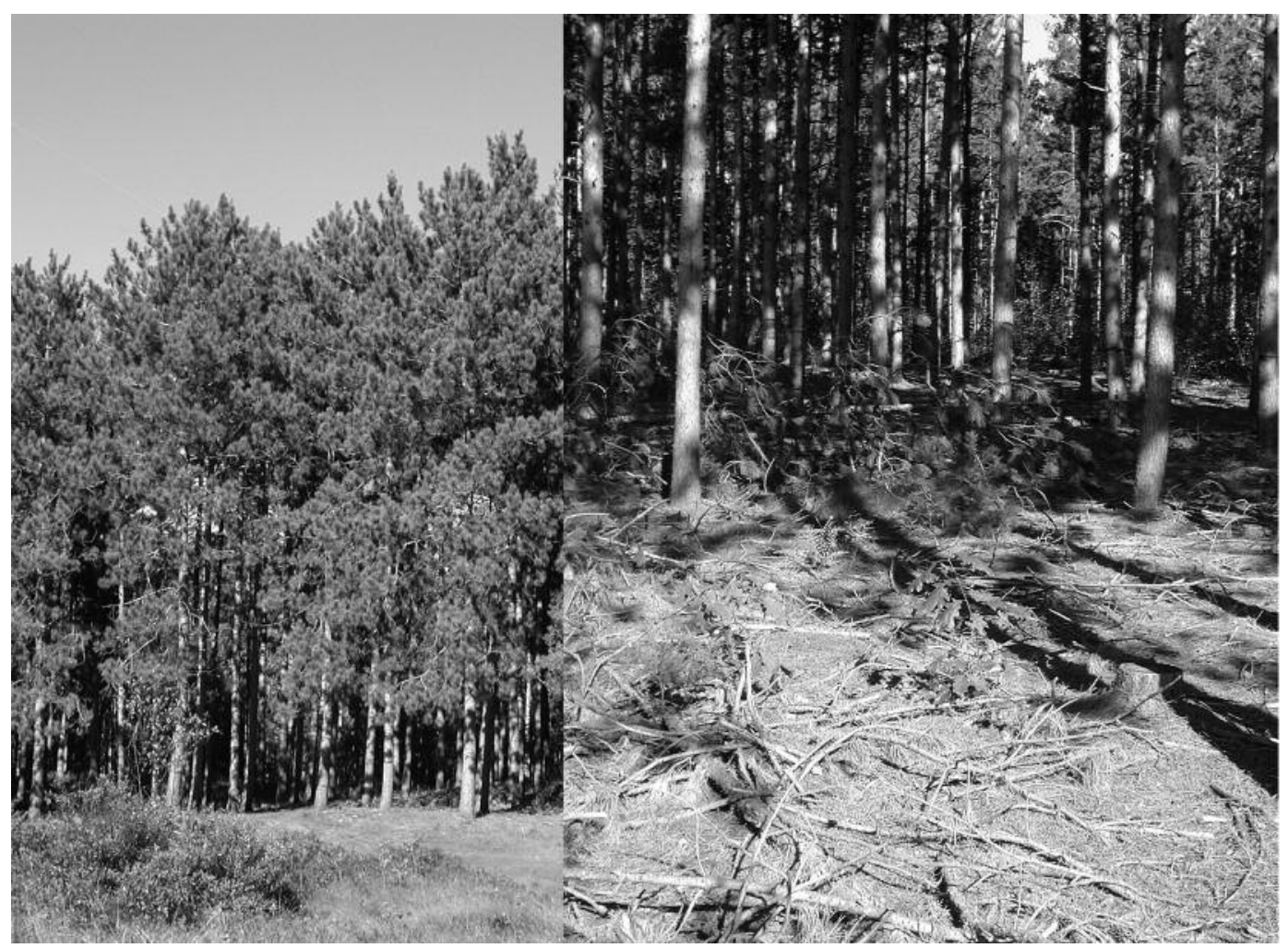

FIgURE 2. The Red Pine (Pinus resinosa) plantation on the north side of the clearing. Left showing the height and density of trees looking northeast from the centre of the clearing. Right showing the very sparse vascular plant cover in deep pine needle litter along transect 3 in the plantation. Photos by P. M. Catling, September 2009.

\section{Methods}

\section{The Study Area}

The Constance Bay Sandhills are located on the south side of the Ottawa River in the western portion of the city of Ottawa at $45.49586^{\circ} \mathrm{N}$, and $-76.08684^{\circ} \mathrm{W}$. For a general discussion of the biodiversity and history of the area see Catling et al. (2010) and for information on the flora see White (2004a, 2004b*). The restoration of The Sandhills was undertaken by the Ontario Ministry of Natural Resources (OMNR). The restoration area from which the trees were removed (subsequently referred to as the clearing) is a little less than a hectare in extent. It is mostly flat or gently sloping and lower than the surrounding land. The restoration involved removal of all planted Red and Jack Pine trees in the late 1980s from an area planted in the early 1950s (approximately 40 years earlier). The duff was not removed and the regeneration of savannah was initially poor. In 1989 OMNR staff Don Cuddy and Kim Taylor supervised removal of the duff to expose the sandy soil. Seeds from plants in the firebreaks were planted in both bare sand and in areas of remaining duff. Records of these plantings were kept but subsequently lost. The restoration work is estimated to have required five people over a period of less than two weeks. By 1991, many savannah plants had developed in the sandy areas including many that had not been planted (D. Cuddy, personal. communication). The OMNR intended the restored area to be the first step in an extensive restoration requested by professional biologists and local naturalists (Wilson 1984; Catling et al. 2010) but after the first steps in 19871992, OMNR experienced a series of cutbacks and the work ceased. Responsibility for management became unclear but it appears to have belonged to the township of Torbolton until it was turned over to the City of Ottawa in 2000. Over the last few decades there have been low intensity fires in parts of the clearing (regarded by biologists visiting the site as having been beneficial) that were evidently started by young people partying in the site (and/or possessing ecological knowledge).

To evaluate the effectiveness of the restoration it is necessary to determine the extent to which the restored area was dominated by native pre-plantation vegetation. In 1941, prior to the conversion of the savannah which dominated much of The Sandhills to a pine plantation, Porsild (1941) indicated that "on gently 
sloping ground and in level places Vaccinium pennsylvanicum (= angustifolium), Gaylussacia baccata, Myrica asplenifolia, Ceanothus americanus, $C$. ovatus and Arctostaphylos uva-ursi form a dense cover." Later in 1957, but still in advance of destruction, Breitung (1957) described The Sandhills as "treeless and prairie-like in aspect, covered with low shrubs. Of these the primary species are Vaccinium pensylvanicum (= angustifolium), Myrica asplenifolia, Ceanothus americanus, Prunus pumila var. cuneata (= susquehannae), and Gaylussacia baccata.

From these historical landscape descriptions a successful restoration would include the establishment of a self-sustaining lower elevation, level area dominated by a dense growth of the previously mentioned dominant shrub species. Success was also considered with respect to biodiversity measures applied to the vascular flora and an indicator group of insects.

\section{Data Collection}

In September 2009, 17 years after the restoration clearing was created, vegetation was sampled with 20 one $\mathrm{m}^{2}$ quadrats, $3 \mathrm{~m}$ apart along four transects, each $80 \mathrm{~m}$ long. Two of these transects were in the restoration clearing and two were in the adjacent plantation. The adjacent plantation samples included one planted with Red Pine (north side), the other planted with Jack Pine. Orthopteran insects (grasshoppers, crickets, katydids) were sampled by sweeping vegetation with a net and direct hand capture along the same four transects one $m$ on either side of the transect line. The Orthoptera survey was carried out during clear, sunny weather and 45 minutes was spent collecting along each transect line. This amount of time was sufficient to capture and record all Orthopteran insects along the transects. The timing of the Orthopteran survey was appropriate since most species are adult at this time and some spring species that are only half grown nymphs are large enough to be identifiable.

Most insects and some plants are represented by voucher specimens in the $\mathrm{CNCI}$ and $\mathrm{DAO}$ collections of Agriculture and Agri-food Canada on the Central Experimental Farm in Ottawa. The names of orthopteroid insects correspond to those used in Vickery and Kevan (1985) and Cantrall (1968). The names of plants are taken largely from Kartesz and Meachum (1999).

\section{Data Analysis}

To determine the extent of successful restoration of native savanna vegetation at The Sandhills, the vegetation and orthopteran insect fauna of the two transects in the restored clearing was compared with that of two transects representing the surrounding plantation.

For vascular plants the species presence was recorded in each quadrat. Cover for each species in each quadrat was estimated as a percentage of the one $\mathrm{m}^{2}$ ground surface covered by living material of that species. It could exceed $100 \%$ due to overlap of extensive cover. There was no height restriction so an esti-

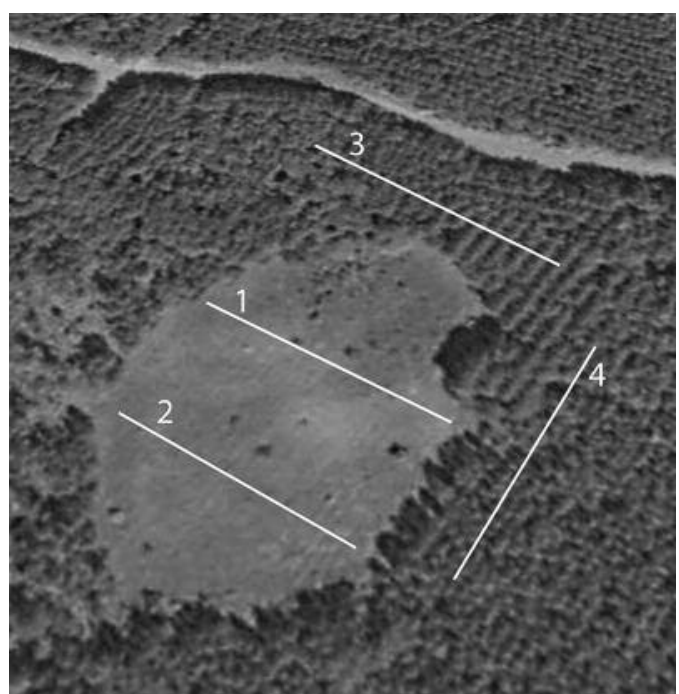

FIGURE 3. Aerial view of the opening showing the position of four transects. Reproduced from Google Earth Pro in 2009.

mate of tree cover was also included. This cover estimate corresponds to $1 / 2$ of the surface area of a plant above a quadrat. Mean \% frequency and mean \% cover of species were compared between the restoration clearing and the adjacent plantation and within these two sites. The numbers of orthopteroid insects were simply tallied for comparison.

The measures of biodiversity employed were: (1) total number of species and individuals for both plants and orthopteroid insects (species richness) and for plants the frequency and cover of each species; (2) the number of regionally rare species for plants through reference to the list of "distributionally significant" species developed by Brunton (2005*); (3) the reciprocal of Simpson's Index based on probability which weights common and dominant species applied to both plant cover and frequency data; and (4) Brillouin's Index which employs numbers of individuals or in this case instances, (i.e., frequency), and assumes no replacement, applied only to frequency data. The computations were made using Ecological Methodology software (Krebs 2008*). See also Krebs (1999) for details on these biodiversity measures. The Simpson's and Brillouin's indices both take heterogeneity into account. This includes consideration of the number of common species and the evenness of occurrence. The reciprocal of Simpson's Index approximates the number of equally common species required to generate the heterogeneity observed in the sample. Biodiversity that includes a large number of equally common species is often perceived as more valuable than that which includes a few dominants accompanied by a large number of rare species. 


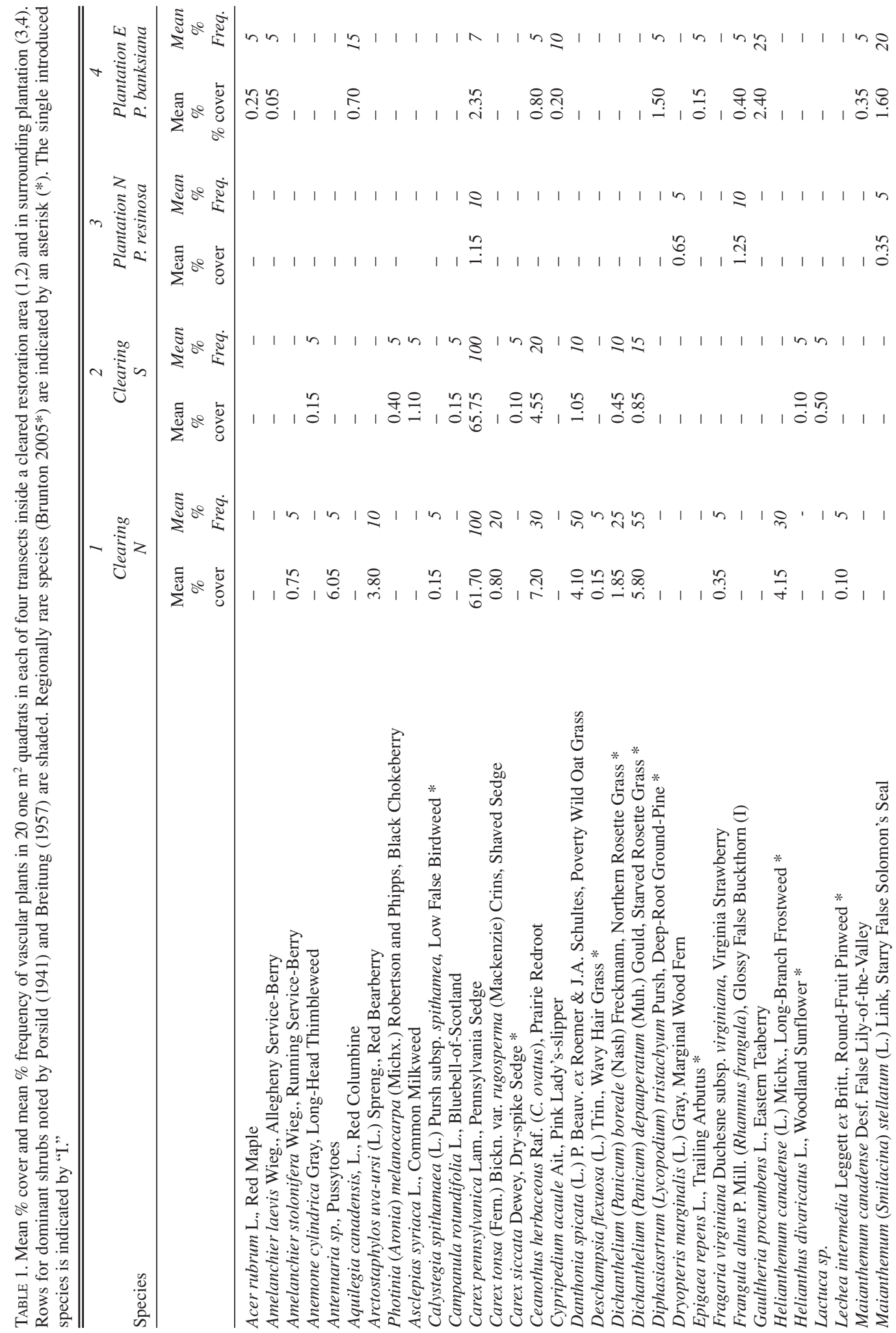




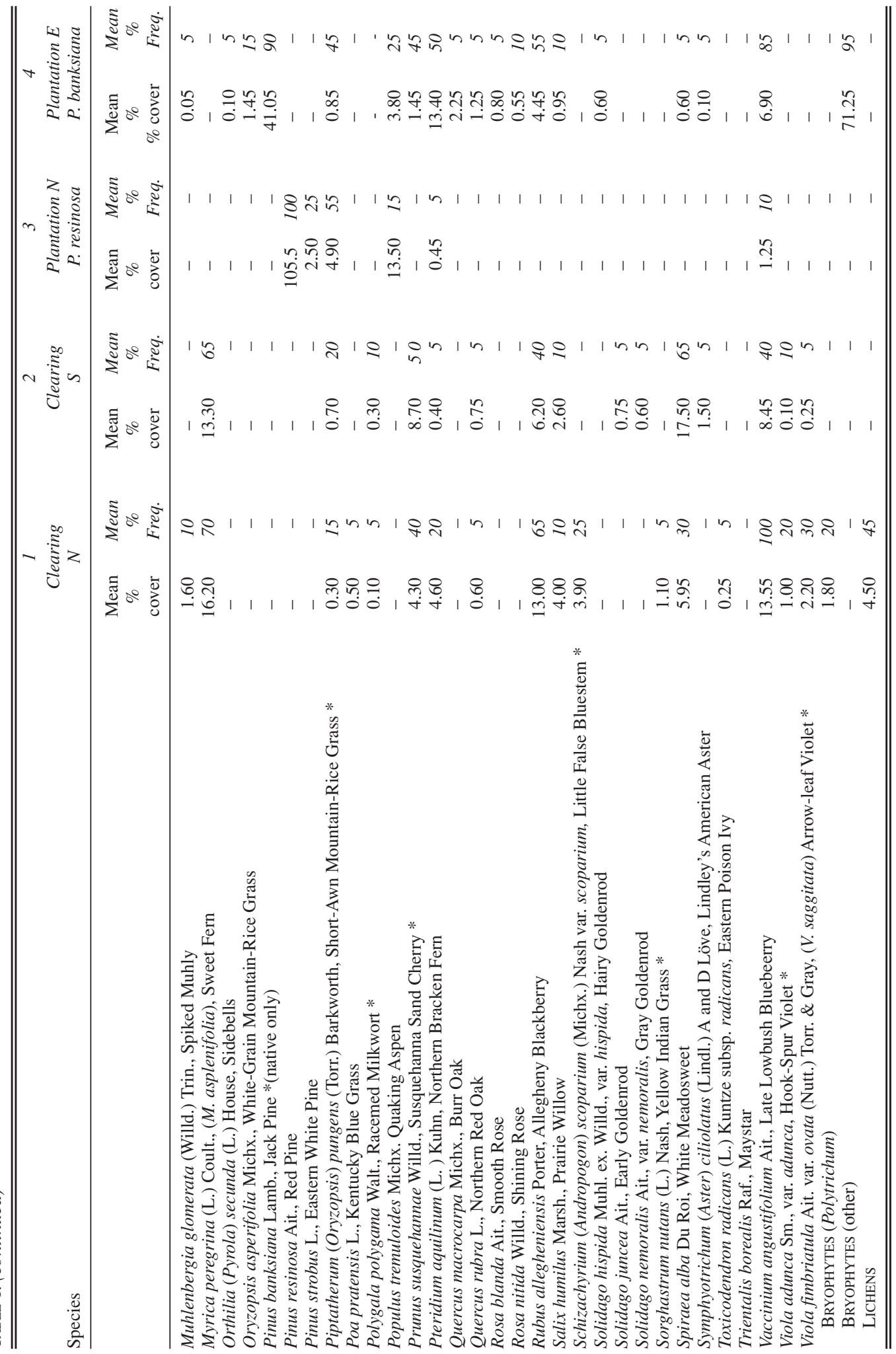




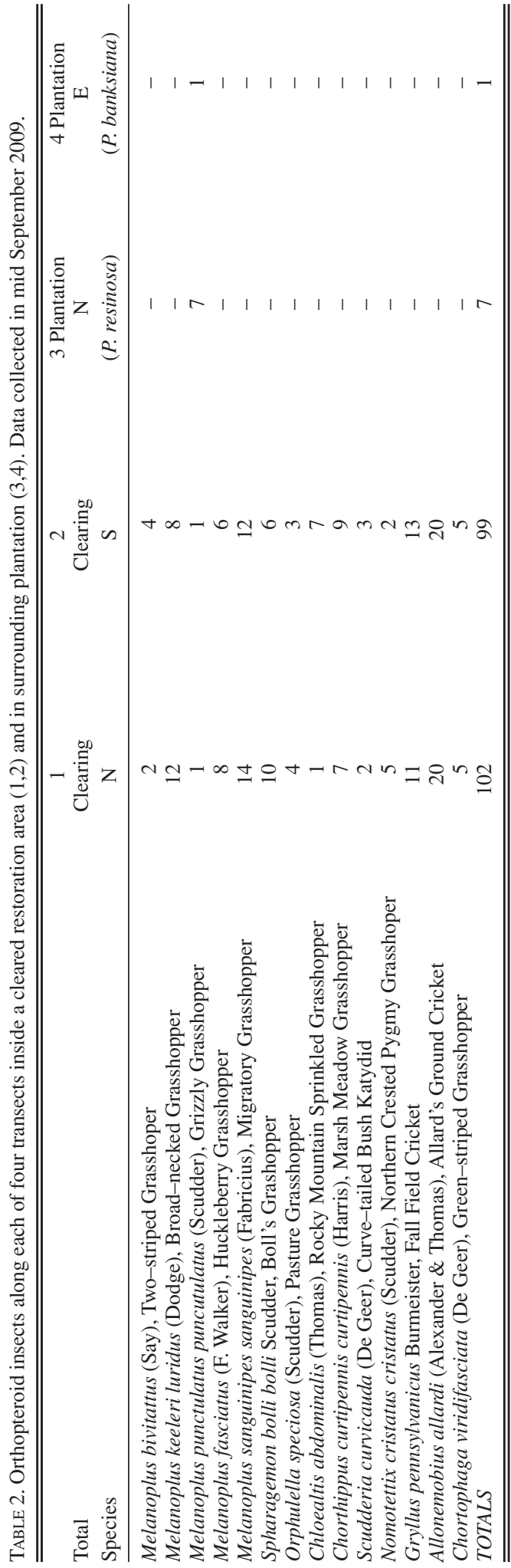

In some situations plant diversity may be high but individuals may be small and or weak and non-productive with implications for dependent species in the ecosystem such as plant-feeding insects and insect- and plant-eating birds. To evaluate this visually, we have used graphs of ranked (highest to lowest) cover values without the single dominant species (Carex pennsylvanica in the clearing and Red Pine or Jack Pine in the plantation) where the greater the area below the graph line indicates greater contribution to the total cover of non-dominant species, suggesting better "condition" of sub-dominants.

\section{Results}

Return to Savannah Vegetation

Of the seven native shrubs reported by Porsild (1941) and Breitung (1957) as characteristic of the savannah, five (Arctostaphylos uva-ursi, Ceanothus ovatus, Myrica asplenifolia, Prunus susquehannae, Vaccinium angustifolium) were present in the restored area and most were dominants. The major dominant in the restored area was the native sedge Carex pensylvanica, a characteristic species of savannah. With the dominance of a characteristic native graminoid plant and the same native shrubs reported as pre-plantation dominants, the natural vegetation appears to have been successfully restored.

\section{Biodiversity Increase}

The two clearing transects and the Jack Pine plantation transect had similar numbers of vascular plant species and similar values for various biodiversity index measurements that were much higher than those for the Red Pine plantation (Table 2).

With regard to rare species (as defined in White $2004 \mathrm{a}, \mathrm{b})$ that were seen within $10 \mathrm{~m}$ of transects, there were only three in the surrounding plantation: Piptatherum (Oryzopsis) pungens occurred in both the Red Pine and Jack Pine; Epigaea repens and Diphasiastrum (Lycopodium) tristachyum, occurred only in the latter. The situation was very different in the clearing transects where a total of 19 regionally rare species were present within $10 \mathrm{~m}$ of transects including: Bromus kalmii, Calystegia spithamaea subsp. spithamea, Carex siccata, Cyperus houghtonii, Deschampsia flexuosa, Dichanthelium (Panicum) boreale, Dichanthelium (Panicum) depauperatum, Elymus canadensis, Helianthemum canadense, Helianthus divaricatus, Lechea intermedia, Lithospermum caroliniense var. croceum, Piptatherum (Oryzopsis) pungens, Polygala polygama, Prunus susquehannae, Rubus pennsylvanicus, Schizachyrium (Andropogon) scoparium var. scoparium, Sorghastrum, nutans, Viola adunca var. adunca, and Viola fimbriatula var. ovata. A similar occurrence of regionally rare species can be seen in the quadrat data (Tables 1 and 3).

The only introduced plant observed in the plantation was Frangula alnus. Since it had low frequency and cover values there was no need to take this species into 
TABLE 3. Number of vascular plant species, number of rare (distributionally significant) following Brunton (2005*) and values for the Brillouin's and reciprocal of Simpson's biodiversity indices for each of four transects inside a cleared restoration area $(1,2)$ and in surrounding plantation $(3,4)$.

\begin{tabular}{lccccc}
\hline \hline & & & & 3 & 4 \\
& $\begin{array}{c}\text { Total } \\
\text { Species }\end{array}$ & $\begin{array}{c}1 \\
\text { Clearing N }\end{array}$ & $\begin{array}{c}2 \\
\text { Clearing S }\end{array}$ & $\begin{array}{c}\text { Plantation N } \\
\text { P. resinosa }\end{array}$ & $\begin{array}{c}\text { Plantation E } \\
\text { P. banksiana }\end{array}$ \\
\hline Number of species & 63 & 33 & 27 & 10 & 31 \\
Number of rare species & 15 & 13 & 9 & 1 & 3 \\
Brillouin's Index (freq.) & n/a & 4.198 & 3.748 & 2.413 & 3.963 \\
Simpson's Index (cover) & n/a & 15.223 & 9.999 & 4.042 & 12.218 \\
Simpson's Index (freq.) & n/a & 16.818 & 10.804 & 4.040 & 12.472 \\
\hline \hline
\end{tabular}

account at the present time, but given its seriously invasive nature (Catling and Porebski 1994) it is conceivable that it will impact future restoration as it becomes more common in the area.

The ranked cover graphs indicated that the clearing transects had greater cover of non-dominant species (Figure 4), suggesting that more shrubby and herbaceous species were in good condition than in the plantation transects. This was confirmed by visual observation of a number of species, such as Vaccinium angustifolium and Prunus susquehannae. Both were fairly frequent in the Jack Pine plantation transect, but rarely produced flowers or fruit there. Abundant flower and fruit production by robust shrubs of both of these species was observed in the clearing transects.

\section{Re-establishment of Orthopteroid Insects}

The diversity of orthopteropid insects was much higher in the clearing (Table 3), where 14 species and 201 individuals were recorded, as opposed to eight individuals of one species in the surrounding plantation. The only species found in the pine plantation was Melanoplus punctulatus punctulatus, which lives in and feeds on Red Pine. Among the species present in the clearing, the populations of Spharagemon bolli bolli and Melanoplus fasciatus constitute impressive occurrences of locally uncommon species strongly associated with natural, open habitats. The former is usually associated with open sand with sparse grass and shrub cover. The latter is associated with open areas with huckleberry and/or blueberry (Vickery and Kevan 1985).

\section{Discussion}

\section{Return to Savannah Vegetation}

A limitation of the present restoration attempt was the small geographic area involved, which in the context of the landscape, results in a lack of topographic variation. The restored area is low and flat. Had it been larger, it may have included higher and steeper areas and it would likely have included different assemblages of species and more domination by those preferring drier and sandier conditions. Regardless of this limitation, the restoration of pre-settlement and pre-plantation vegetation based on limited effort was successful.

\section{Biodiversity Increase}

The fact that the Jack Pine plantation transect had higher biodiversity than one of the clearing transects may be explained by the fact that these pines with relatively open canopies were established in an open area of original vegetation that was able to survive in a depleted condition due to the continuation of somewhat open conditions. The remnant species of open habitats along with species of more shaded conditions that spread into the plantation apparently combined to produce a relatively high diversity. The Red Pine plantation excluded much more light and also gave rise to dense needle litter which buried ground flora.

Although the Jack Pine plantation had biodiversity values approaching that of the restored clearing, the smaller number of regionally rare species resulted in a lower level of biodiversity significance there. Furthermore the smaller amount of non-dominant vegetation cover in the Jack Pine plantation, than in the clearing, attests to the poor condition of much of the plantation flora with a resultant lesser value to pollinators and plant-feeding insects.

\section{Re-establishment of Orthopteroid Insects}

The much higher diversity of an indicator group of plant dependent insects in the clearing is not surprising considering the higher plant diversity and better condition of the flora, and the general finding that insect diversity tracks plant diversity (e.g. Knops et al. 1999). The origin of these insects is an interesting question since they were not found in the adjacent plantation. It seems most likely that they followed open habitat along paths and firebreaks into the site. It is also conceivable that they persisted in very low numbers in the Jack Pine plantation where the ground flora persisted in a depleted condition.

\section{Conclusions}

The restoration of savannah from pine plantation has not been extensive enough in Ontario to provide evidence for success on the basis of statistical analysis of many replicated samples. This study however, does provide some useful evidence pertaining to a single situation. It strongly suggested that restoration of a savannah destroyed by a pine plantation can be eas- 


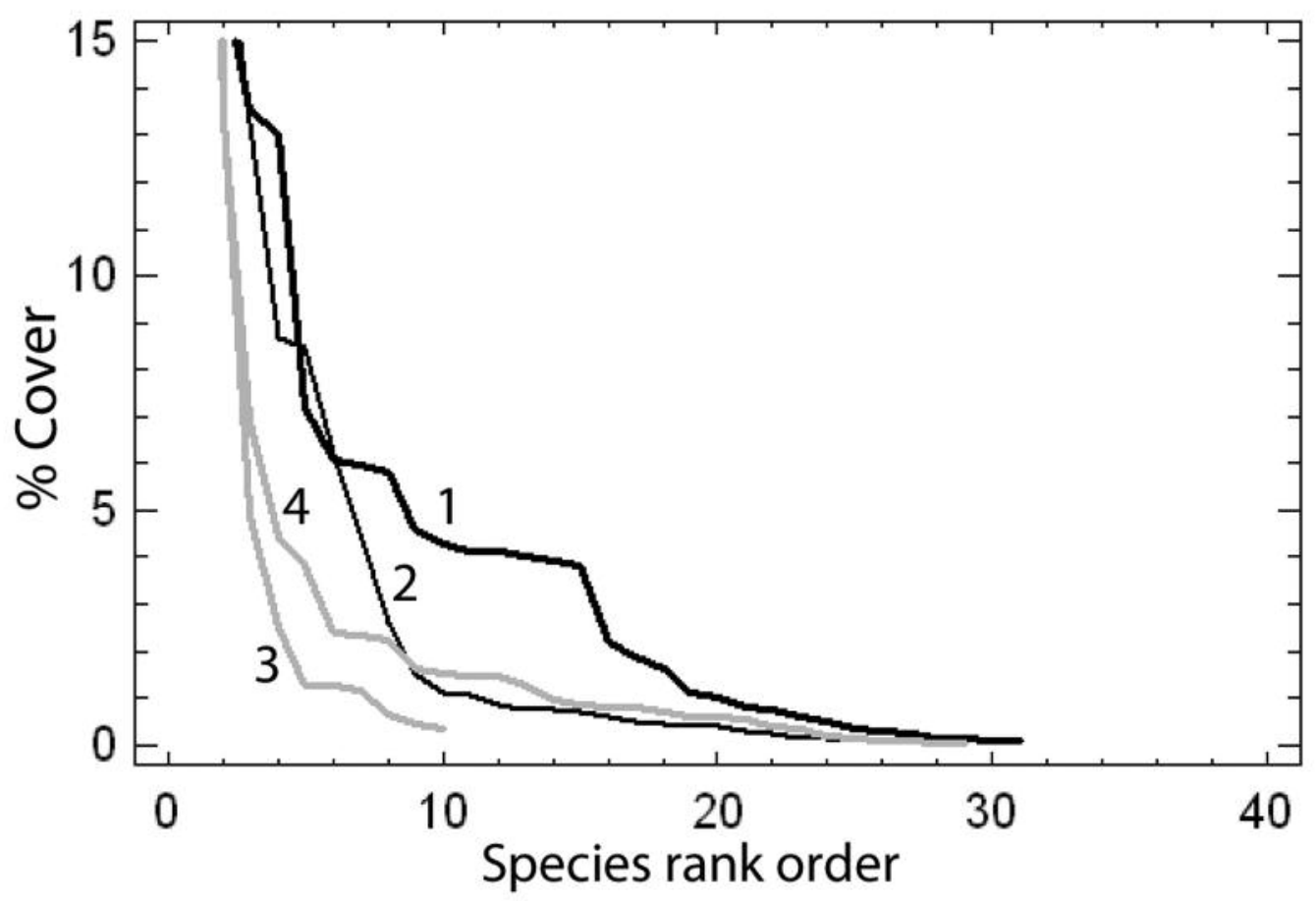

FIGURE 4. Graphs of ranked (highest to lowest) cover values without the single dominant species (Carex pennsylvanica in the clearing and Red Pine or Jack Pine in the plantation). The greater the area below the graph line indicates greater contribution to the total cover of non-dominant species, suggesting better "condition" of sub-dominant species.

ily accomplished, especially if remnants of the previous ecosystem remain in the immediate vicinity and if some are introduced during the early stages of restoration. The importance of a local source of plants for recolonization has been established in other studies (Brudvig et al. 2009). In the present situation, both plants and insects may have been able to take advantage of open edges along paths as dispersal corridors.

Not only was the savannah vegetation restored but native biodiversity in The Sandhills study area was also substantially promoted by returning the plantation to savannah. The results have included: (1) major increase in the number of regionally rare species; (2) improvement in the condition of species of open habitat compared to that seen in the plantation; and (3) vast improvement in the diversity and abundance of an indicator group of plant dependent insects which occurred without direct intervention. Tools for monitoring and measuring success include historical descriptions, and data from quadrats leading to comparisons of diversity, biodiversity indices and species rank order graphs. At this site and at all others where restoration actions have been taken there should be continuing monitoring to establish the extent and continuation of beneficial effects. Both here and elsewhere the restoration should be extended to the maxi- mum possible extent so as to protect the largest amount of biodiversity. Considering the relatively low costs there is no reason not to indulge in extensive restoration of open habitat on plantation lands.

\section{Acknowledgments}

Don Cuddy and Sean Thompson of the Ontario Ministry of Natural Resources provided background materials. Don Cuddy shared information from his personal notebooks. Jeff Skevington and Dan Brunton kindly commented on the manuscript.

Documents Cited (marked * in text)

Brunton, D. F. 2005. Vascular plants of the City of Ottawa, with identification of significant species, Appendix A of Muncaster Environmental Planning and Brunton Consulting Services. 2005. Urban Natural Areas Environmental Evaluation Study, Final Report. Planning and Growth Management Department, City of Ottawa, Ottawa.

Kasel, S. and T. Meers. 2004. Restoration of former pine plantations in Australia: Revegetation techniques, pine wildling control, and the importance of land use history. Society for Ecological Restoration International Online. https://www.ser.org/serbc/pdf/287_former_pine_plantati ons_Australia.pdf.

Krebs, C. 2008. Ecological Methodology, programs for ecological methodology, $2^{\text {nd }}$ edition. Exeter Software, Setauket, New York. 
Ontario Ministry of Natural Resources. 2009. Peter's Woods Park Management Plan. Darlington Provincial Park. Bowmanville. 51 pages.

Taggart, J. B. 1990. Inventory, classification and preservation of coastal plain savannas in the Carolinas. Ph.D. dissertation, University of North Carolina, Chapel Hill, North Carolina.

White, D. J. 2004a. Rare plant inventory and management recommendations for Torbolton Forest. Transportation, Utilities and Public Works Department, City of Ottawa.

White, D. J. 2004b. Rare plant manual. Transportation, Utilities and Public Works Department, City of Ottawa.

Wilson, S. 1984. Restoration of the native vegetation of the Constance Bay Sandhills, Regional Municipality of OttawaCarleton. The Plant Press 2(1): 6-7.

\section{Literature Cited}

Bakowsky, W., and J. Riley. 1994. A survey of the prairies and savannas of southern Ontario. Pages 7-16 in Proceedings of the Thirteenth North American Prairie Conference: Spirit of the Land, Our Prairie Legacy. August 6-9, 1992. Edited by R. Wickett, P. Dolan Lewis, A. Woodliffe and P. Pratt, Corporation of the City of Windsor, Windsor, Ontario.

Breitung, A. J. 1957. Vascular flora on the sand dunes at Constance Bay, Ontario. Le Naturaliste canadien 84 (3-4): 79-87.

Brudvig, L. A., E. I. Damschen, J. J. Tewksbury, N. M. Haddad and D. J. Levey. 2009. Landscape connectivity promotes plant biodiversity spillover into non-target habitats. Proceedings of the National Academy of Sciences of the United States of America. 106(23): 9328-9332.

Cantrall, I. J. 1968. An annotatred list of the Dermaptera, Dictyoptera, Phasmatoptera, and Orthoptera of Michigan. Michigan Entomologist 1: 299-346.

Catling, P. M., and S. Carbyn. 2005. Invasive Scots Pine (Pinus sylvestris) replacing Corema (Corema conradii) heathland in the Annapolis valley, Nova Scotia, Canada. Canadian Field-Naturalist 119: 237-244

Catling, P. M., and B. King. 2008. Natural recolonization of cultivated land by native prairie plants and its enhancement by removal of Scots Pine, Pinus sylvestris. Canadian FieldNaturalist 121: 89-91.

Catling, P. M., and Z. S. Porebski. 1994. The history of invasion and current status of Glossy Buckthorn, Rhamnus frangula, in southern Ontario. Canadian Field-Naturalist 108: 305-310.
Catling, P. M., K. Spicer, and D. F. Brunton. 2010. The history of the Constance Bay Sandhills - decline of a biodiversity gem in the Ottawa valley. Trail and Landscape 44(1): 106-122.

Clarke, C. H. D. 1971. The cult of the Red Pine. Ontario Naturalist 9: 14-15.

Gilliam, F. S., and W. J. Platt. 2006. Conservation and restoration of the Pinus palustris ecosystem. Applied Vegetation Science 9: 7-10.

Houseman, R. C., and R. C. Anderson. 2002. Effects of Jack Pine plantation management on barrens flora and potential Kirtland's Warbler nest habitat. Restoration Ecology 10: 27-36.

Kartesz, J. T., and C. A. Meacham. 1999. Synthesis of the North American Flora, Version 1.0 North Carolina Botanical Garden, Chapel Hill, North Carolina.

Knops, J. M., H., D. Tilman, N. M. Haddad, S. Naeem, C. E. Mitchell, J. Haarstad, M. E. Ritchie, K. M. Howe, P. B. Reich, E. Siemann, and J. Groth. 1999. Effects of plant species richness on invasion dynamics, disease outbreaks, insect abundances and diversity. Ecology Letters 2: 286-293.

Krebs, C. 1999. Ecological methodology, $2^{\text {nd }}$ edition. Addison, Wesley Longman Inc., New York. 620 pages.

Noss, R. F., E. T. LaRoe III, and J. M. Scott. 1995. Endangered ecosystems of the United States: a preliminary assessment of loss and degradation. Biological Report 28. U.S. Department of Interior, National Biological Service, Washington, D.C., 58.

Porsild, A. E. 1941. A relic flora on sand dunes from the Champlain Sea in the Ottawa valley. Canadian FieldNaturalist 55: 66-72.

Rodger, L. 1998. Tallgrass Communities of Southern Ontario: A Recovery Plan. World Wildlife Fund Canada and the Ontario Ministry of Natural Resources. 66 pages. www.tallgrassontario.org/Publications/TallgrassRecovery Plan.pdf

Vickery, V. R., and D. K. M. Kevan. 1985. The insects and arachnids of Canada, part 14. The grasshoppers, crickets and related insects of Canada and adjacent regions. Ulonata: Dermaptera, Cheleutoptera, Notoptera, Dictuoptera, Grylloptera, and Orthoptera. Agriculture Canada Research Branch Publication 1777. Ottawa. Ontario. 918 pages.

Received 16 April 2010

Accepted 4 June 2010 